\title{
ADSORPSI METHYLENE BLUE (MB) MENGGUNAKAN ABU LAYANG BATUBARA TERAKTIVASI LARUTAN NaOH
}

\author{
Umi Dwijayanti $^{1}$, Gunawan ${ }^{1 *}$, Didik Setyo Widodo ${ }^{1}$, Abdul Haris ${ }^{1}$, Linda Suyati ${ }^{1}$, Retno Ariadi \\ Lusiana $^{1}$ \\ ${ }^{1}$ Departemen Kimia, Universitas Diponegoro, J1. Prof. Sudharto SH, Tembalang, Semarang, Indonesia \\ gunawan@live.undip.ac.id, retno.lusiana@live.undip.ac.id
}

Artikel Info
Diterima
tanggal
12.09 .2019
Disetujui
publikasi
tanggal
30.042020
Kata kunci : abu
layang
teraktivasi,
adsopsi,
methylene blue

\section{ABSTRAK}

Penelitian tentang adsorpsi methylene blue (MB) oleh abu layang batubara teraktivasi $\mathrm{NaOH}$ telah dilakukan. Aktivasi abu layang dilakukan dengan menggunakan metode hidrotermal pada temperatur $80^{\circ} \mathrm{C}$ selama $12 \mathrm{jam}$. Abu layang yang sudah teraktivasi dikarakterisasi menggunakan FTIR, dan studi adsorpsi dengan melakukan variasi $\mathrm{pH}$, waktu kontak, dan konsentrasi adsorbat. Karakterisasi FTIR menunjukkan adanya silikat atau aluminat dari abu layang teraktivasi yang bertanggung jawab pada adsopsi MB yaitu vibrasi tekuk ikatan Si atau Al dengan $\mathrm{O}$ pada bilangan gelombang $420-500 \mathrm{~cm}^{-1}$. Abu layang teraktivasi dapat mengadsorpsi zat warna MB pada $\mathrm{pH} 7$ dengan waktu kontak optimum 90 menit. Adsorpsi MB mengikuti pola isoterm Langmuir dan memiliki kapasitas adsorpsi sebesar 500 mg/g.

\section{ABSTRACT}

Research of adsorption of methylene blue (MB) by using activated coal fly ash adsorbent had been conducted. The activation process was carried out using hydrothermal method at a temperature of $80{ }^{\circ} \mathrm{C}$ for $12 \mathrm{~h}$. The activated fly ash was characterized using FTIR, then it was used as adsorbent for $\mathrm{MB}$ by varied $\mathrm{pH}$, contact time, and adsorbate concentration. FTIR characterization shows the presence of silicate or aluminate from activated fly ash that is responsible to the MB adsorption, namely the bending bond vibration of $\mathrm{Si}$ or $\mathrm{Al}$ with $\mathrm{O}$ at the wave number of $420-500 \mathrm{~cm}^{-1}$. Activated fly ash can adsorb $\mathrm{MB}$ dye at $\mathrm{pH} 7$ with an optimum contact time of $90 \mathrm{~min}$. Adsorption of $\mathrm{MB}$ follows the Langmuir isotherm and it has an adsorption capacity of $500.0 \mathrm{mg} / \mathrm{g}$.

\section{PENDAHULUAN}

Penggunaan zat warna sintetik pada berbagai industri menyebabkan limbah cair zat warna organik yang non biodegradable dalam jumlah besar dan berpotensi menyebabkan pencemaran lingkungan. Salah satu pewarna yang sering digunakan adalah methylene blue (MB). Pewarna ini sebagai pewarna kertas yang dikombinasikan dengan zat warna lain. MB memiliki gugus benzena yang menyebabkan zat warna ini sulit untuk didegradasi, kalaupun dimungkinkan dibutuhkan waktu yang lama (Christina dkk., 2007). Senyawa ini bila terlalu lama berada di

doi: http://dx.doi.org/10.23960/aec.v5.i1.2020.p01-14

Anal.Environ.Chem. 
lingkungan akan menjadi sumber penyakit karena bersifat toksik, menyebabkan mutasi genetik dan berpengaruh pada reproduksi (Hawley, 1981).

Penelitian pengurangan zat warna limbah cair telah banyak dilakukan, salah satunya dengan adsorpsi. Menurut Wanchanthuek dan Thapol (2011) pengolahan limbah zat warna dengan adsorpsi memiliki keefektifan yang tinggi. Dalam proses adsorpsi dibutuhkan adsorben untuk mengadsorpsi adsorbat. Salah satu kegunaan adsorben adalah untuk menyerap zat warna dalam pengolahan limbah industri tekstil (Lynch, 1990). Berkembangnya industri yang menghasilkan limbah zat warna diikuti dengan semakin tingginya kebutuhan adsorben. Untuk mengatasi hal tersebut perlu diupayakan keragaman sumber bahan baku adsorben sehingga dapat mengurangi kebutuhan industri terhadap adsorben (Retnowati, 2005).

Dalam penelitian ini digunakan metode adsorpsi dengan menggunakan abu layang yang dihasilkan dari transformasi, pelelehan atau gasifikasi dari material anorganik yang terkandung dalam batubara (Molina dan Poole, 2004). Besarnya kandungan alumina silika dan karbon yang rendah memungkinkan abu layang digunakan sebagai adsorben yang murah dan efektif untuk penghilangan zat warna MB dalam larutan (Sunardi, 2007). Pengurangan zat warna pada limbah tekstil dengan abu layang murni memberikan kapasitas adsorpsi sebesar 6,0 mg/g (Janos dkk., 2003). Abu layang teraktivasi $\mathrm{HCl}$ memiliki potensi adsorpsi MB lebih besar di larutan berair dengan kapasitas adsorpsi sebesar 14,28 mg/g (Banerjee dkk., 2014). Berdasarkan keberhasilan tersebut, maka dalam pada penelitian ini dilakukan studi adsorpsi MB oleh abu layang yang diaktivasi menggunakan $\mathrm{NaOH}$. Menurut Irani dkk, (2009) larutan alkali dapat bereaksi dengan Si dan Al dari abu layang, sehingga dapat menghasilkan ikatan polimer yang kuat. Penelitian ini bertujuan mengetahui kemampuan $\mathrm{NaOH}$ untuk aktivasi abu layang, karakterisasi abu layang teraktivasi dan aplikasinya untuk adsorpsi MB dengan variasi $\mathrm{pH}$, waktu kontak, dan konsentrasi adsorbat.

\section{METODE}

\section{Alat dan Bahan}

Alat: alat gelas standar penelitian, cawan petri, neraca analitik, oven, stirer, desikator, thickness meter, Ultrasonic Homogenizer, dan instrumen FTIR (Perkin Elmer).

Bahan: abu layang batubara dari PLTU Tanjung Jati B Jepara, methylene blue (MB) (Merck), $\mathrm{H}_{2} \mathrm{SO}_{4}$ (Merck), $\mathrm{NaOH}$ (Merck), $\mathrm{HCl}$ (Merck), akuades. 


\section{Prosedur}

\section{Preparasi Abu Layang Batubara}

Pencucian Abu Layang Batubara. Abu layang dicuci dengan akuades untuk menghilangkan pengotor kemudian dikeringkan dengan oven pada suhu $110^{\circ} \mathrm{C}$ selama 12 jam. Padatan yang dihasilkan dihaluskan, kemudian diayak dengan ayakan lolos 100 mesh.

\section{Aktivasi dengan penambahan $\mathrm{NaOH}$}

Dalam gelas kimia yang berisi $100 \mathrm{~g}$ abu layang ditambahkan $300 \mathrm{~mL} \mathrm{NaOH}(\mathrm{NaOH}$ divariasi 1 dan $4 \mathrm{M}$ ). Setelah itu direfluks pada suhu $80{ }^{\circ} \mathrm{C}$ dengan waktu 12 jam sambil diaduk dengan pengaduk. Kemudian, abu layang disaring menggunakan corong buchner dan dicuci dengan akuades sampai $\mathrm{pH}$ netral. Abu layang dikeringkan menggunakan oven pada suhu $110{ }^{\circ} \mathrm{C}$ selama 12 jam.

\section{Preparasi Larutan Uji}

Pembuatan larutan induk MB (Gambar 1) 1000 mg/L dilakukan dengan melarutkan 1 g MB ke dalam labu ukur $1000 \mathrm{~mL}$ lalu ditambahkan akuades sampai tanda batas. Untuk larutan MB yang digunakan dalam proses adsorpsi, pengukuran standar digunakan dari larutan MB $100 \mathrm{mg} / \mathrm{L}$ dengan melakukan pengenceran larutan induk.

\section{Penentuan Panjang Gelombang Maksimum Larutan MB}

Absorbansi larutan MB $3 \mathrm{mg} / \mathrm{L}$ diukur dengan spektrofotometer UV-Vis pada panjang gelombang 400-800 nm sehingga didapatkan panjang gelombang maksimum sebesar $664 \mathrm{~nm}$.

\section{Pembuatan Kurva Kalibrasi Larutan Standar MB}

Larutan zat warna MB dengan konsentrasi 1, 2, 3, 4 dan $5 \mathrm{mg} / \mathrm{L}$ diukur absorbansinya menggunakan spektrofotometer UV-Vis pada panjang gelombang $664 \mathrm{~nm}$.

\section{Adsorpsi Methylene blue}

Variasi Dosis Adsorben

Sebanyak 37,5; 50; 62,5; 75 dan $100 \mathrm{mg}$ abu layang teraktivasi dan $50 \mathrm{~mL}$ larutan MB $50 \mathrm{mg} / \mathrm{L}$ dimasukkan ke dalam erlenmeyer $100 \mathrm{~mL}$. Kemudian diaduk menggunakan pengaduk magnet 200 rpm selama 60 menit. Hasil yang diperoleh disaring, dan filtratnya dianalisis menggunakan spektrofotometer UV-Vis.

$\underline{\text { Variasi } \mathrm{pH}}$ 
Sebanyak 37,5 mg abu layang teraktivasi dan $50 \mathrm{~mL}$ MB $50 \mathrm{mg} / \mathrm{L}$ pada $\mathrm{pH}$ 2, 4, 6, 7, 8, 10 dan 12 dimasukkan ke dalam 7 erlenmeyer $100 \mathrm{~mL}$. Pengaturan $\mathrm{pH}$ dilakukan dengan penambahan $\mathrm{HCl} \mathrm{0,1} \mathrm{M} \mathrm{atau} \mathrm{NaOH}$ 0,1 M. Larutan tersebut diaduk dengan pengaduk magnet $200 \mathrm{rpm}$ selama 60 menit, kemudian hasilnya disaring, dan diukur absorbansinya dengan spektrofotometer UVVis.

\section{Variasi Waktu Kontak}

Abu layang teraktivasi sebanyak $37,5 \mathrm{mg}$ dan $50 \mathrm{~mL}$ MB $30 \mathrm{mg} / \mathrm{L}$ pada $\mathrm{pH}$ optimum dimasukkan ke dalam 5 erlenmeyer 100 mL. Selanjutnya diaduk dengan pengaduk magnet 200 rpm selama 30, 60, 90, 120, dan 150 menit, dan disaring. Filtrat larutan diukur absorbansinya dengan spektrofotometer UV-Vis.

\section{Variasi Konsentrasi MB}

Limapuluh mL MB 10, 30, 50, 70, dan $90 \mathrm{mg} / \mathrm{L}$ pada $\mathrm{pH}$ optimum dimasukkan ke dalam 5 erlenmeyer $100 \mathrm{~mL}$. Kemudian dimasukkan 37,5 mg abu layang teraktivasi ke dalam erlenmeyer tersebut. Setelah diaduk dengan pengaduk magnet 200 rpm pada waktu optimunya, dilakukan penyaringan, dan filtratnya dianalisis dengan spektrofotometer UV-Vis.

\section{Penentuan Kapasitas Adsorpsi}

Kapasitas adsorpsi maksimum menurut (Mall dkk, 2006) dihitung berdasarkan persamaan berikut :

$$
\frac{\mathrm{Ce}}{\mathrm{qe}}=\frac{\mathrm{Ce}}{q_{\max }}+\frac{1}{K_{L} q_{\max }}
$$

$\mathrm{q}_{\max }$, $\mathrm{q}_{\mathrm{e}}$ dan $\mathrm{K}_{\mathrm{L}}$ masing-masing adalah kapasitas maksimal adsorpsi (mg/g), jumlah molekul zat warna yang teradsorpsi per satuan massa adsorben (mg/g), Konstanta Langmuir (L/g).

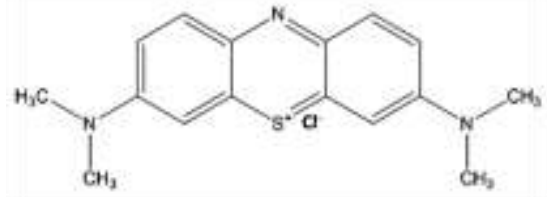

Gambar 1. Struktur kimia methylene blue.

\section{Karakterisasi}

Karakterisasi abu layang murni, abu layang teraktivasi dan abu layang yang sudah menyerap MB, dilakukan dengan menggunakan FTIR untuk melihat perubahan gugus fungsi 
yang ada. Pengujian dilakukan dengan Pelet $\mathrm{KBr}$ yaitu dengan mencampurkan sampel sebelum dan sesudah perlakuan dengan kristal $\mathrm{KBr}$ selanjutnya dibuat pelet. Selanjutnya dianalisis dengan FT-IR.

\section{HASIL DAN PEMBAHASAN}

\section{Proses Aktivasi Abu Layang Batubara}

Komposisi kimia abu layang menunjukkan bahwa sebagian besar tersusun atas $\mathrm{SiO}_{2}$ dan $\mathrm{Al}_{2} \mathrm{O}_{3}$ yang mempunyai gugus aktif sehingga dapat digunakan sebagai adsorben zat warna. Namun, pembakaran batubara yang memerlukan suhu tinggi sering menghasilkan abu layang dengan kandungan $\mathrm{SiO}_{2}$ dalam fase kristal dan kandungan karbon yang tidak terbakar cukup tinggi yang menyebabkan penurunan kapasitas adsorpsi zat warna oleh abu layang. Penurunan kapasitas adsorpsi ini dapat dicegah dengan mengaktivasi adsorben (Yan dkk., 2003).

Menurut Ojha dkk (2004) reaksi yang terjadi selama proses peleburan antara komponen abu layang $\mathrm{SiO}_{2}$ dan $\mathrm{Al}_{2} \mathrm{O}_{3}$ dengan $\mathrm{NaOH}$ adalah sebagai berikut:

$$
\begin{array}{ll}
2 \mathrm{NaOH}(\mathrm{s})+\mathrm{Al}_{2} \mathrm{O}_{3}(\mathrm{~s}) & \rightarrow 2 \mathrm{NaAlO}_{2}(\mathrm{~s})+\mathrm{H}_{2} \mathrm{O}(\mathrm{g}) \\
2 \mathrm{NaOH}(\mathrm{S})+\mathrm{SiO}_{2} & \rightarrow \mathrm{Na}_{2} \mathrm{SiO}_{3}(\mathrm{~s})+\mathrm{H}_{2} \mathrm{O}(\mathrm{g}) \\
10 \mathrm{NaOH}(\mathrm{s})+2 \mathrm{SiO}_{2} .3 \mathrm{Al}_{2} \mathrm{O}_{3}(\mathrm{~s}) & \rightarrow 2 \mathrm{Na}_{2} \mathrm{SiO}_{3}(\mathrm{~s})+\mathrm{NaAlO}_{2}(\mathrm{~s})+\mathrm{O}_{2}(\mathrm{~g})
\end{array}
$$

Aktivasi adsorben dilakukan untuk mengetahui kemampuan adsorben setelah aktivasi. Hasil aktivasi adsorben dapat dilihat pada Gambar 2.

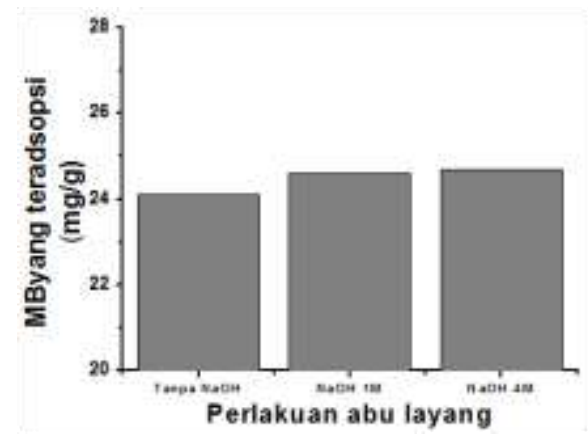

Gambar 2. Hubungan antara MB yang teradsorpsi oleh abu layang baik tanpa dan dengan perlakuan dengan $\mathrm{NaOH}$ untuk menjerap $50 \mathrm{~mL}$ MB $50 \mathrm{mg} / \mathrm{L}$. 
Gambar 2 menunjukkan MB teradsorpsi tertinggi adalah abu layang teraktivasi $\mathrm{NaOH} 4$ M sebesar 24,68 mg/g. Menurut Nurhayati dkk (2013) abu layang yang diaktivasi NaOH 4 M merupakan kondisi penyerapan optimal karena mempunyai kristal rhambohedral dari alumunium oksida dan kristal heksagonal dari silikon oksida, sedangkan pada aktivasi $1 \mathrm{M}$ hanya terbentuk kristal heksagonal dari silikon oksida. Struktur kristal berpengaruh pada kekuatan dinding permukaan adsorben, semakin kuat dinding kristal maka akan menambah kestabilan adsorben abu layang ketika terjadi tekanan fisik dari luar seperti tekanan saat pengadukan sehingga dapat meningkatkan kapasitas adsorpsi terhadap $\mathrm{MB}$. Adanya $\mathrm{NaOH}$ akan bereaksi dengan gugusgugus aktif yang terdapat di dalam abu layang yaitu silika dan alumina yang membentuk produk-produk silikat dan aluminat. Silikat dan aluminat tersebut yang bertanggung jawab tehadap pengikatan MB (Irani dkk, 2009).

\section{Variasi Dosis Adsorben}

Dosis adsorben merupakan salah satu faktor yang mempengaruhi proses adsorpsi. Semakin banyak dosis adsorben yang digunakan semakin efektif proses adsorpsi yang terjadi. Variasi adsorben dilakukan untuk mengetahui dosis adsorben maksimum dalam mengadsorpsi MB. Hasil variasi dosis adsorben dapat dilihat pada Gambar 3.

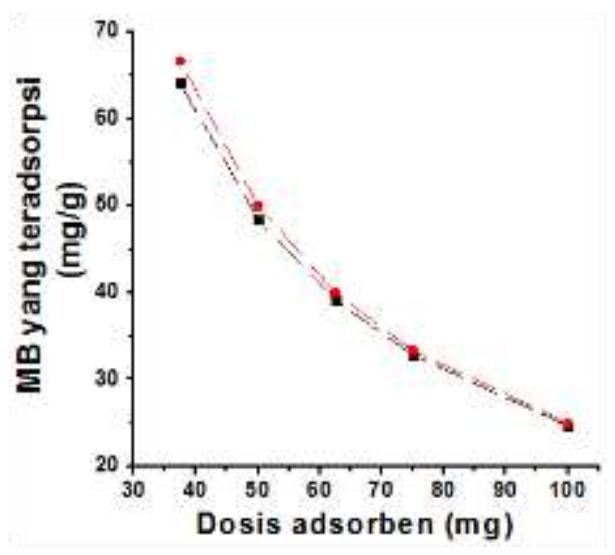

Gambar 3. Kurva hubungan antara dosis adsorben (mg) dengan MB yang teradsorpsi yang ditunjukkan dengan kurva kotak hitam. Sedangkan kurva bulat merah adalah MB teoritis yang teradsorpsi semua oleh adsorben. $[\mathrm{MB}]_{\mathrm{o}}=50 \mathrm{mg} / \mathrm{L}$.

Gambar 3 terlihat perubahan MB yang teradsorpsi tidak terlalu signifikan dibandingkan dengan teoritis MB diserap semua oleh adsorbat. Semakin banyak dosis adsorben yang 
digunakan maka MB terjerap semua karena dengan meningkat jumlah partikel adsorben lebih banyak biru metilen melekat pada permukaannya. Dari grafik terlihat bahwa semakin banyak dosis adsorben yang digunakan akan menurunkan MB yang terjerap untuk dosis adsorben 37,5 dan $100 \mathrm{mg}$ masing-masing memiliki kapasitas adsorpsi sebesar 64,06 dan 24,67 mg/g. Selanjutnya dosis adsorben yang digunakan untuk adsorpsi MB adalah 37,5 mg karena dengan dosis tersebut sudah memberikan nilai adsorpsi MB yang besar.

\section{Variasi pH}

Variasi $\mathrm{pH}$ untuk mengetahui kondisi $\mathrm{pH}$ yang optimum untuk penjerapan $\mathrm{MB}$ menggunakan abu layang teraktivasi. Hasil variasi pH ini dapat dilihat pada Gambar 4.

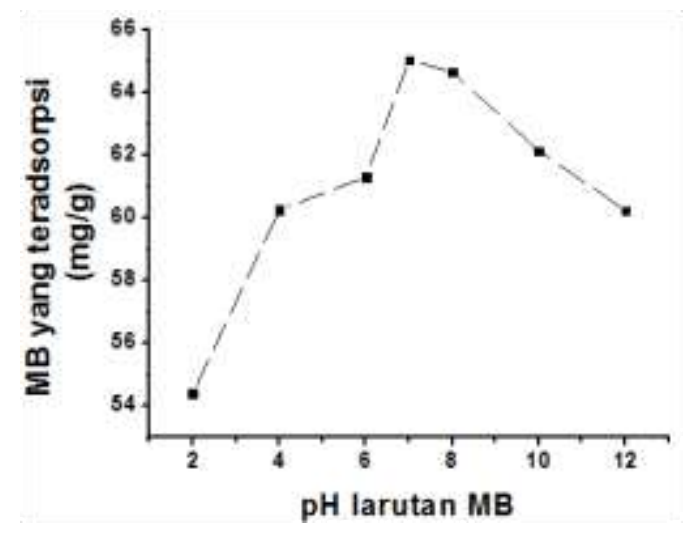

Gambar 4. Kurva hubungan antara pH dengan kapasitas adsorpsi (mg/g) MB.

Hasil tersebut menunjukkan proses adsorpsi terbesar pada $\mathrm{pH}$ netral sebesar $65,04 \mathrm{mg} / \mathrm{g}$. Pada $\mathrm{pH} 2$ penyerapan relatif rendah. Hal ini dikarenakan adanya persaingan antara $\mathrm{H}^{+}$dan gugus aktif abu layang teraktivasi untuk berikatan dengan larutan zat warna yang terdisosiasi menjadi ion-ionnya. Tumin dkk., (2008) mengatakan bahwa pada pH rendah adsorpsi kecil, karena adanya $\mathrm{H}^{+}$dari larutan akan mencegah terjadinya interaksi zat warna dengan gugus aktif yang terdapat pada permukaan adsorben yaitu aluminat dan silikat (Irani dkk, 2009). Hasil penyerapan pada pH 2 sampai $\mathrm{pH} 8$ terjadi kenaikan karena permukaan adsorben cenderung terionisasi melepas ion $\mathrm{H}^{+}$sehingga permukaan adsorben menjadi negatif. Hal ini menyebabkan terjadinya interaksi elektrostatik antara permukaan abu layang teraktivasi dengan zat warna. Pada $\mathrm{pH}$ sampai pH 12 terjadi penurunan adsorpsi karena ion $\mathrm{OH}^{-}$yang terlalu banyak mengakibatkan persaingan antar ion $\mathrm{OH}^{-}$untuk berikatan dengan $\mathrm{MB}$ semakin besar, sehingga daya serapnya 
semakin berkurang. Permukaan abu layang mempunyai muatan positif pada $\mathrm{pH}$ kurang dari 9.4 dan bermuatan negatif pada $\mathrm{pH}$ lebih dari 9,4. Selanjutnya $\mathrm{pH} \mathrm{9,4}$ adalah $\mathrm{pH}$ PZC $(\mathrm{pH}=0)$ yang diperoleh dari memasukkan adsorben ke dalam larutan $\mathrm{KNO}_{3}, 0,01 \mathrm{M}$ pada $\mathrm{pH}$ tertentu dan diperoleh $\mathrm{pH}_{\mathrm{i}}-\mathrm{pH}_{\mathrm{f}}\left(\mathrm{pH}_{\mathrm{i}}\right.$ sebelum ditambah adsorben dan $\mathrm{pH}_{\mathrm{f}}$ sebagai $\mathrm{pH}$ setelah ditambah adsorben) selanjutnya dibuat grafik $\left(\mathrm{pH}_{\mathrm{i}}-\mathrm{pH}_{\mathrm{f}}\right)$ terhadap $\mathrm{pH}$ sehingga diperoleh $\mathrm{pH}$ PzC (Mall dkk, 2006; Olievera Brito dkk, 2010).

\section{Variasi Waktu Kontak Adsorpsi}

Penentuan waktu kontak optimum dilakukan setelah diketahui pH optimum adsorpsi. Penentuan waktu kontak bertujuan untuk mengetahui berapa waktu yang dibutuhkan untuk mencapai penyerapan optimum MB oleh abu layang teraktivasi. Menurut teori tumbukan, kecepatan reaksi bergantung pada jumlah tumbukan per satuan waktu. Semakin banyak tumbukan yang terjadi maka reaksi semakin cepat berlangsung sampai terjadi kondisi setimbang. Hasil variasi waktu kontak antara MB dan abu layang teraktivasi ditunjukkan pada Gambar 5.

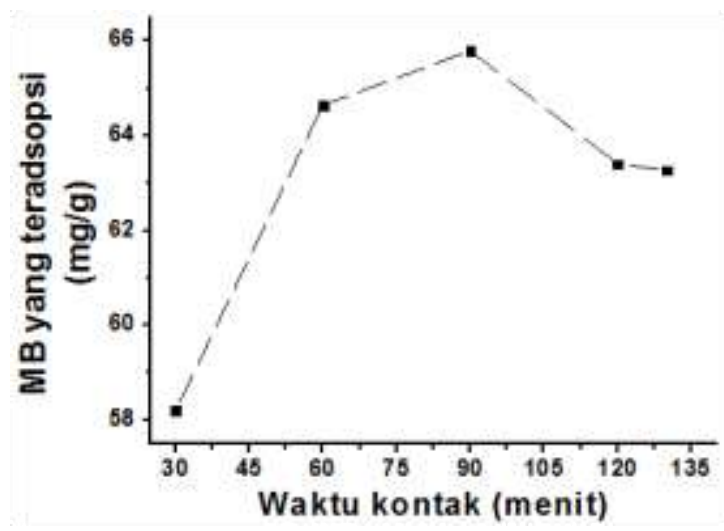

Gambar 5 Kurva hubungan waktu kontak (menit) dengan kapasitas adsorpsi (mg/g) MB.

Gambar 5 menunjukkan bahwa pada waktu kontak 30 sampai 90 menit terjadi peningkatan adsorpsi dan terjadi kesetimbangan pada waktu kontak 90 menit sebesar 39,12 mg/g. Hal ini dapat dikarenakan pada awalnya banyak situs aktif adsorben yang kosong, sehingga kecenderungan larutan untuk terserap ke adsorben semakin tinggi karena gugus aktif pada adsorben belum berinteraksi secara optimal. Pada waktu kontak 120 menit penyerapan yang 
terjadi mengalami penurunan, hal ini dikarenakan semakin lama waktu kontak antara adsorben dan adsorbat memungkinkan untuk terjadinya peningkatan penyerapan zat warna, namun jika terlalu lama dapat menurunkan tingkat penyerapan. Semakin lama waktu kontak juga dapat mengakibatkan desorpsi, yaitu terlepasnya zat warna yang sudah terikat oleh adsorben. Bernard dan Jimoh (2013) menunjukkan bahwa setelah adsorpsi mencapai keadaan setimbang pada waktu kontak optimum, penambahan waktu kontak antara adsorben dan adsorbat selanjutnya tidak memberikan pengaruh signifikan terhadap penyerapan zat warna. Hastuti dkk., (2012) mengatakan kontak fisik antara zat warna dengan adsorben yang terlalu lama menyebabkan zat warna lama-kelamaan terlepas kembali ke dalam larutan. Hal ini mengakibatkan jumlah zat warna tertukar semakin besar, yang mengindikasikan daya serapnya juga menurun.

\section{Variasi Konsentrasi}

Perlakuan variasi konsentrasi bertujuan untuk memperoleh informasi berapa konsentrasi yang dibutuhkan untuk mencapai penyerapan optimum pada zat warna MB oleh abu layang teraktivasi. Hasil adsorpsi MB dengan variasi konsentrasi ditampilkan pada Gambar 6.

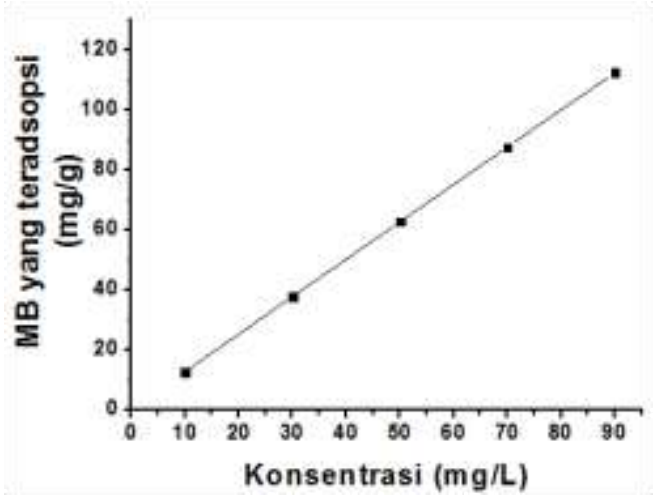

Gambar 6. Kurva hubungan antara konsentrasi dengan kapasitas adsorpsi (mg/g) MB.

Gambar 6 menunjukkan kemampuan penyerapan MB meningkat seiring dengan meningkatnya konsentrasi MB. Kemampuan penyerapan MB dapat dilihat dari nilai kapasitas adsorpsi. Peningkatan kapasitas adsorpsi terjadi karena adanya penyerapan MB yang semakin banyak dari larutan yang teradsorpsi secara kimia pada permukaan adsorben. 


\section{Penentuan Kapasitas Adsorpsi maksimum}

Kapasitas adsorpsi maksimum dapat diperoleh dari perhitungan hasil jumlah MB terserap dan konsentrasi zat warna setimbang pada saat variasi konsentrasi MB yang diinterpretasikan dengan model isoterm adsorpsi Langmuir.

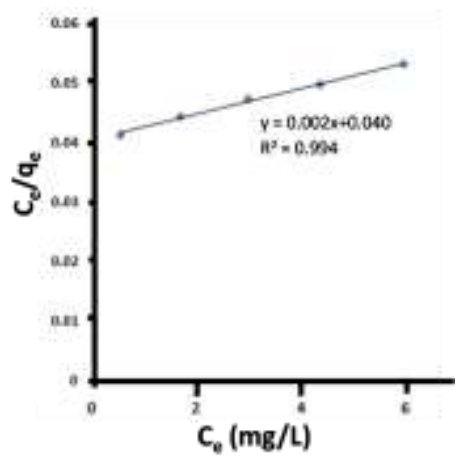

Gambar 7 Grafik isoterm adsorpsi Langmuir adsorpsi MB oleh abu layang teraktivasi

Tabel 1. Perbandingan kapasitas adsorpsi Langmuir dari berbagai jenis adsorben dalam menyerap MB.

\begin{tabular}{|c|c|c|c|}
\hline No. & Adsorben & $\begin{array}{c}\text { Kapasitas } \\
\text { Adsorpsi (mg/g) }\end{array}$ & Referensi \\
\hline 1. & Abu Layang Murni & 6,00 & Janos dkk., 2003 \\
\hline 2. & Biomassa beras bekas & 8,13 & Rehman dkk., 2012 \\
\hline 3. & Zeolit NaA & 64,8 & Sapawe dkk., 2013 \\
\hline 4. & Selulosa dari Kertas Buram & 909,09 & Crisyanti dkk, 2018 \\
\hline 5. & $\begin{array}{l}\text { Penyaringan Termodifikasi Silika- } \\
\text { Asam Salisilat }\end{array}$ & 27,28 & Labiebah dkk, 2019 \\
\hline 6. & Aktivasi Abu Layang dengan $\mathrm{HCl}$ & 14,28 & Banerjee dkk., 2014 \\
\hline 7. & Aktivasi Abu Layang dengan $\mathrm{NaOH}$ & 500 & Penelitian Sekarang \\
\hline
\end{tabular}

Berdasarkan Gambar 7, maka didapatkan hubungan $\mathrm{C}_{\mathrm{e}} / \mathrm{q}_{\mathrm{e}}$ dengan $\mathrm{C}_{\mathrm{e}}$ dari Persamaan 1, sehingga diperoleh persamaan $y=0,002 x+0,040\left(R^{2}=0,994\right)$. Persamaan Langmuir yang diperoleh digunakan untuk menentukan kapasitas adsorpsi dan konstanta kesetimbangan. Hasil perhitungan diperoleh kapasitas adsorpsi maksimum MB pada abu layang teraktivasi sebanyak $500 \mathrm{mg} / \mathrm{g}$ dan konstanta kesetimbangan adsorpsi $\left(\mathrm{K}_{\mathrm{L}}\right)$ 0,05 L/mg. Komparasi hasil adsorben yang berbeda untuk adsorpsi MB disajikan pada Tabel 1. Terlihat kapasitas adsorpsi 
menggunakan adsorben abu layang teraktivasi $\mathrm{NaOH}$ memberikan nilai yang lebih besar yaitu $500 \mathrm{mg} / \mathrm{g}$ dibandingkan adsorben abu layang murni, abu layang teraktivasi $\mathrm{HCl}$, biomassa, zeolit, dan penyaringan termodifikasi. Hanya adsorben selulosa dari kertas buram yang memberikan harga di atas adsorben abu layang termodifikasi. Perbedaan nilai kapasitas adsorpsi disebabkan perbedaan struktur, porositas, gugus fungsi dan luas permukaan masing-masing adsorben (Banerjee, 2014).

\section{Karakterisasi abu layang dengan FT-IR}

Spektra inframerah (FT-IR) bertujuan untuk mengetahui gugus aktif dalam abu layang (murni, teraktivasi $\mathrm{NaOH}$ dan yang sudah menyerap MB). Spektra FTIR disajikan pada Gambar 8. Pada Gambar 8 terlihat bahwa, adsorbansi pada $300-4000 \mathrm{~cm}^{-1}$ yang merupakan daerah karakteristik abu layang. Semua spektra menunjukkan adanya puncak yang tajam pada bilangan gelombang 1250-950 $\mathrm{cm}^{-1}$ yang menunjukkan adanya gugus vibrasi rentang asimetri T-O-T ( $\mathrm{T}=\mathrm{Si}$ atau $\mathrm{Al})$.

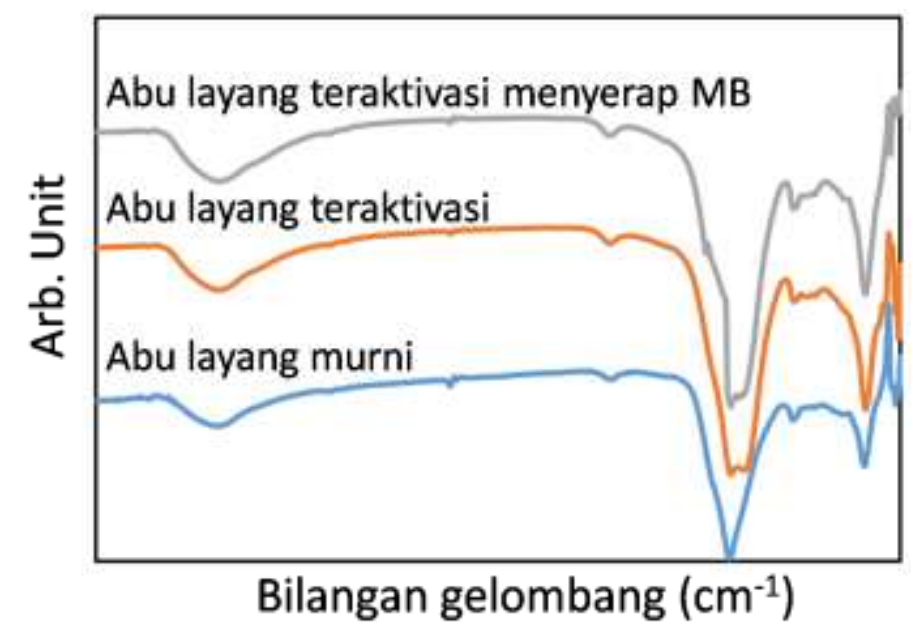

Gambar 8. Spektra FT-IR dari abu layang murni, teraktivasi dan yang menyerap MB.

Tabel 2 terlihat intrepetasi spektrum abu layang pada bilangan gelombang $3433,29 \mathrm{~cm}^{-1}$ yang menunjukkan vibrasi rentangan $-\mathrm{OH}$. Selanjutnya, adanya vibrasi $\mathrm{T}-\mathrm{O}-\mathrm{T}(\mathrm{T}=\mathrm{Si}$ atau $\mathrm{Al}$ ) dan daerah sidik jari gugus $\mathrm{SiO}$ dan $\mathrm{AlOH}$ ditunjukkan pada bilangan gelombang 1087,85 $\mathrm{cm}^{-1}$. Adanya gugus Si-O ditunjukkan oleh bilangan gelombang 794,67 $\mathrm{cm}^{-1}$ yang merupakan vibrasi Si-O. Bilangan gelombang $462,92 \mathrm{~cm}^{-1}$ menunjukkan adanya vibrasi tekuk ikatan T-O $(\mathrm{T}=\mathrm{Si}$ 
atau $\mathrm{Al})$. Spektrum inframerah abu layang teraktivasi ditunjukkan adanya vibrasi rentangan $-\mathrm{OH}$ pada bilangan gelombang $3433,29 \mathrm{~cm}^{-1}$. Adanya vibrasi T-O-T ( $\mathrm{T}=\mathrm{Si}$ atau $\mathrm{Al}$ ) dan daerah sidik jari gugus $\mathrm{SiO}$ dan $\mathrm{AlOH}$ ditunjukkan oleh kemunculan bilangan gelombang 1018,41 $\mathrm{cm}^{-1}$. Kemunculan vibrasi 732,95 $\mathrm{cm}^{-1}$ menunjukkan adanya vibrasi ulur simetri O-Si-O atau O-Al-O. Vibrasi tekuk ikatan $\mathrm{T}(\mathrm{T}=\mathrm{Si}$ atau $\mathrm{Al})$ ditunjukkan pada $\mathrm{n} 462,92 \mathrm{~cm}^{-1}$. Sedangkan pada 308,61 $\mathrm{cm}^{-1}$ terdapat vibrasi pori terbuka. Hal ini memungkinkan abu layang teraktivasi memiliki kemampuan yang efektif untuk menurunkan MB.

Tabel 2. Interpretasi Spektra infra merah abu layang murni, teraktivasi dan sudah menyerap MB.

\begin{tabular}{|c|c|c|c|c|}
\hline \multirow{3}{*}{ No. } & \multicolumn{2}{|c|}{ Frekuensi daerah serapan } & \multirow{3}{*}{ Interpretasi } & \multirow{3}{*}{ Referensi } \\
\hline & \multicolumn{2}{|c|}{$\left(\mathrm{cm}^{-1}\right)$} & & \\
\hline & Hasil analisis & $1 / \kappa$ & & \\
\hline \multirow[t]{3}{*}{1.} & $3433,29^{\text {a) }}$ & \multirow{3}{*}{$3200-3500$} & \multirow{3}{*}{ Vibrasi rentang $-\mathrm{OH}$} & \multirow{3}{*}{$\begin{array}{c}\text { Sastrohamidjojo, } \\
1991\end{array}$} \\
\hline & $3433,29^{b)}$ & & & \\
\hline & $3425,58^{c)}$ & & & \\
\hline 2. & $1182,72^{\mathrm{c})}$ & $1180-1360$ & Vibrasi gusus C-N & Ojha dkk., 2004 \\
\hline \multirow[t]{3}{*}{3.} & $1087,85^{\text {a) }}$ & \multirow{3}{*}{$950-1250$} & \multirow{3}{*}{$\begin{array}{l}\text { Vibrasi } \mathrm{T}-\mathrm{O}-\mathrm{T}(\mathrm{T}=\mathrm{Si} \\
\text { atau } \mathrm{Al})\end{array}$} & \multirow{3}{*}{$\begin{array}{l}\text { Flanigen dkk, } \\
1971\end{array}$} \\
\hline & $1018,41^{b)}$ & & & \\
\hline & $1080,14^{\mathrm{c})}$ & & & \\
\hline \multirow[t]{6}{*}{4.} & $794,67^{\text {a) }}$ & \multirow{3}{*}{$750-820$} & \multirow{3}{*}{$\begin{array}{l}\text { Vibrasi ulur simetri } \\
\text { O-Si-O atau O-Al-O }\end{array}$} & \multirow{3}{*}{$\begin{array}{c}\text { Flanigen dkk, } \\
1971\end{array}$} \\
\hline & $732,95^{b)}$ & & & \\
\hline & $794,67^{c)}$ & & & \\
\hline & $462,92^{\text {a) }}$ & \multirow{3}{*}{$420-500$} & \multirow{3}{*}{$\begin{array}{l}\text { Vibrasi tekuk ikatan } \\
\mathrm{T}-\mathrm{O}(\mathrm{T}=\mathrm{Si} \text { atau } \mathrm{Al})\end{array}$} & \multirow{3}{*}{ Ojha dkk., 2004} \\
\hline & $462,92^{b)}$ & & & \\
\hline & $462,92^{c)}$ & & & \\
\hline \multirow[t]{2}{*}{6.} & $324,04^{\text {a) }}$ & \multirow{2}{*}{$300-420$} & \multirow{2}{*}{$\begin{array}{c}\text { Pembukaan pori } \\
\text { terbuka }\end{array}$} & \multirow{2}{*}{ Ojha dkk., 2004} \\
\hline & $308,61^{b)}$ & & & \\
\hline
\end{tabular}

Keterangan : a) Abu layang murni; b) Abu layang teraktivasi; c) Abu layang dan MB

Spektrum inframerah abu layang teraktivasi yang mengadsorpsi MB muncul puncak kecil pada bilangan gelombang $1182,72 \mathrm{~cm}^{-1}$ yang berasal dari vibrasi $\mathrm{C}-\mathrm{N}$ cincin aromatik $\mathrm{MB}$, adanya puncak baru setelah adsorpsi menunjukkan bahwa MB telah teradsorpsi pada abu layang teraktivasi. Pada vibrasi rentangan $-\mathrm{OH}$ ditunjukkan pada 3425,58 $\mathrm{cm}^{-1}$. Kemunculan bilangan 
gelombang 2862,36 $\mathrm{cm}^{-1}$ menunjukkan adanya vibrasi rentangan $-\mathrm{CH}_{3}$. Selanjutnya, adanya gugus yang mengandung vibrasi $\mathrm{T}-\mathrm{O}-\mathrm{T}(\mathrm{T}=\mathrm{Si}$ atau $\mathrm{Al})$ dan daerah sidik jari gugus $\mathrm{SiO}$ dan AlOH ditunjukkan oleh bilangan gelombang $1080,14 \mathrm{~cm}^{-1}$. Adanya gugus Si-O ditunjukkan oleh $794,67 \mathrm{~cm}^{-1}$ yang merupakan vibrasi Si-O. Bilangan gelombang $462,92 \mathrm{~cm}^{-1}$ menunjukkan adanya vibrasi tekuk ikatan $\mathrm{T}-\mathrm{O}(\mathrm{T}=\mathrm{Si}$ atau $\mathrm{Al})$.

\section{KESIMPULAN}

Abu layang teraktivasi natrium hidroksida dapat menaikkan kapasitas adsorpsi MB. Kondisi optimum adsorpsi MB oleh abu layang teraktivasi terjadi pada $\mathrm{pH} 7$ dan waktu kontak 90 menit, Kapasitas adsorpsi abu layang teraktivasi terhadap larutan zat warna MB sebesar 500 $\mathrm{mg} / \mathrm{g}$ dengan mengikuti model isoterm langmuir.

\section{UCAPAN TERIMA KASIH}

Kepada FSM universitas Diponegoro atas pendanaan dan peralatan yang diberikan.

\section{DAFTAR PUSTAKA}

Banerjee, S., Sharma, G. C., Chattopadhyaya, M. C., dan Chandra, Y., 2014. Kinetic and equilibrium modeling for the adsorptive removal of methylene blue from aqueous solutions on of activated fl y ash ( AFSH ). Biochemical Pharmacology, 2(3), 1870-1880.

Bernard, E dan Jimoh, A., 2013, Adsorption of Pb, Fe, Cu, and Zn From Industrial Electroplating Waste Water by Orange Peel Actived Carbon. International Journal of Enginnering and Applied Science. Vol. 4, No.2, 95-103

Crisyanti, D., Gunawan, dan Haris, A., 2018, Blue methylene retrieval using silica-salicylic acid modified filter, Jurnal Kimia Sains dan Aplikasi, 21(1), 19-23.

Christina P., Mu'nisatun S., Rany Saptaaji dan Marjanto, D., 2007, Studi Pendahuluan Mengenai Degradasi Zat Warna Azo (Metil Orange) dalam Pelarut Air Menggunakan Mesin Berkas Elektron, JFN, Vol.1, No.1.

Flanigen, E.M., Khatami, H., dan Szymanski, H.A., 1971, Infrared Structural Studies of Zeolite Framework. Molecular Sieve Zeolite-I, American Society Advanced in Chemistry Series

Hastuti, S., S.H. Mawahib, dan Setyaningsih, 2012, Penggunaan Serat Daun Nanas Sebagai Adsorben Zat warna Precion Red Mx 8b. Jurnal Ekosains, Vol.4, No. 1 : 41-47,

Hawley, 1981, Condensed Chemical Dictionary, edisi ke-11, Van Nortrand Reinhold, New York

doi: http://dx.doi.org/10.23960/aec.v5.i1.2020.p01-14

Anal.Environ.Chem. 
Irani K, Fansuri H. dan Atmaja L., 2009, Modifikasi Permukaan Abu Layang Menggunakan $\mathrm{NaOH}$ dan Aplikasinya untuk Geopolimer: Sifat Fisik dan Mekanik, Tesis Magister, FMIPA ITS, Surabaya.

Janos P., Buchtová H., dan Rýznarová M., 2003, Adsorption of dyes from aqueous solutions onto fly ash, Water Res. 4938-4944.

Labiebah, G., Gunawan, Djunaidi, M.C., Haris, A., dan Widodo, D.S., 2019, Removal of methylene blue using used paper powder, Jurnal Kimia Sains \& Aplikasi, 22(1), 23-28.

Lynch C.T., 1990, Practical Handbook of Material Science,Edisi ke-2, New York.

Mall, I. D., Srivastava, V. C., Kumar, G. V. A. dan Mishra, I. M., 2006, Characterization and Utilization of Mesoporous Fertilizer Plant Waste Carbon for Adsorptive Removal of Dyes from Aqueous Solution, Colloids and Surfaces A: Physicochemical and Engineering Aspects 278(1-3): 175-187

Nurhayati N.D., dan Yuli S., 2013, Aktivasi dan Karakterisasi Fly Ash sebagai Material Adsorben Limbah Timbal, Makalah Seminar Nasional Kimia dan Pendidikan Kimia V.

Ojha, K., Pradhan, N.C., dan Samanta, A.N., 2004. Zeolit From Fly Ash: Synthesis and Characterization, Vol.27, Bulletin Material Science, 555-564.

Oliveira Brito, S.M., Andrade, H.M.C., Soares, L.F., de Azevedo R.P., 2010, Brazil nut shells as a new biosorbent to remove methylene blue and indigo carmine from aqueous solutions $J$. Hazard. Mater. 174, 84-92.

Rehman, Muhammad S. U., Ilgook Kim, dan Jong-In H, 2012, Adsorption of Methylene Blue Dye from Aqueous Solution by Sugar Extracted Spent Rice Biomass, Journal of Carbohydrate Polymers, 1314-1322.

Retnowati, 2005, Efektivitas Ampas Sebagai Adsorben Alternatif Limbah Cair Industri Tekstil, FMIPA IPB, Bogor.

Sapawe, N., Jalil A. A., dan Triwahyono S., 2013, Cost-effective Microwave Rapid Synthesis of Zeolit NaA for Removal of Methylene Blue, Journal of Chemical Engineering, 388-398.

Sastrohamidjojo, H., 1991, Spektroskopi, Yogyakarta, Liberty

Sunardi, 2007, Unsur Kimia, Deskripsi dan Pemanfaatannya, Yrama Widya, Bandung

Tumin, N.D.; Chuah, A.L; Zawani, Z., dan Rasid, S.A., 2008, Adsorption of Copper from Aqueous Solution by Elais Guineensis Kernel Activated Carbon, Journal of Engineering Science and Technology, 2, 180-189.

Wanchanthuek, R. dan Thapol, A., 2011, Kinetic Study of Methylene Blue Adsorption Over $\mathrm{MgO}$ from PVA Template Preparation, J. Environ.Sci.Tech 552-559

doi: http://dx.doi.org/10.23960/aec.v5.i1.2020.p01-14

Anal.Environ.Chem. 